\title{
STATE OWNERSHIP AND BANK PERFORMANCE: EVIDENCE FROM ISLAMIC BANKS IN TURKEY
}

\author{
DOI: 10.17261/Pressacademia.2021.1514 \\ PAP- V.14-2021(40)-p.148-149
}

\section{Ozlem Akin ${ }^{1}$, S. Mehmet Ozsoy ${ }^{2}$}

${ }^{1}$ Ozyegin University, Faculty of Business, Istanbul, Turkey. ozlem.akin@ozyegin.edu.tr, ORCID: 0000-0003-2115-8416

${ }^{2}$ Ozyegin University, Faculty of Business, Istanbul, Turkey mehmet.ozsoy@ozyegin.edu.tr, ORCID: 0000-0002-9391-7859

\section{To cite this document}

Akin, O., Ozsoy, S.M., (2021). State ownership and bank performance: evidence from Islamic banks in Turkey. PressAcademia Procedia (PAP), 14, 148-149.

Permanent link to this document: http://doi.org/10.17261/Pressacademia.2021.1514

Copyright: Published by PressAcademia and limited licensed re-use rights only.

\section{ABSTRACT}

Purpose- Shlefier and Vishny (1997) suggest that state-owned firms perform worse than the private firms because of the contradictory incentives of managers. The previous literature tests this theory in the context of the banking sector. More specifically, there has been a discussion on political distortions of state ownership. On the one hand, state-owned banks contribute to economic development (Stiglitz,1993). On the other hand, politicians might use state-owned banks for their own interest (Shlefier and Vishny, 1994; Shlefier, 1998). Empirical evidence shows that politicians indeed use those banks for their own benefit (La Porta et al., 2002; Sapienza, 2004; Dinc, 2005; Khwaja and Mian, 2005, Carvalho, 2014). The purpose of this study is to test this theory in the context of Islamic banking. We contribute to the debate by focusing on profitability of state-owned banks and comparing it with that of private banks. Turkey provides an excellent setting to test this theory as the Turkish government established Islamic banks with the aim of supporting Islamic banking sector that was run by private Islamic banks beforehand.

Methodology- We obtained a quarterly detailed regulatory dataset from The Bank Association of Turkey for the time period $2014 \mathrm{Q} 1$ 2017Q4. The study employs a descriptive approach to compare the profitability of state-owned Islamic banks with that of privately-owned Islamic banks in Turkey. The profitability of banks is measured by return-on-assets which is a widely used measure in banking literature (see e.g. Beck et al., 2013).

Findings- The analysis shows that on average the profitability of state-owned Islamic banks is slightly higher than that of the private Islamic banks when we exclude the year they established. Our time series analysis shows that state-owned Islamic banks performed at least as good as private Islamic banks in every quarter of our sample. The results contradict what Shleifer and Vishny (1997) suggest.

Conclusion- Overall, our analysis provide insights into the state ownership in the banking sector in general and in the Islamic banking sector specifically. Although our results point that on average state-owned and private banks perform similarly, further research could identify and compare the determinants of the bank profitability of these groups of banks. In general, understanding profitability is the key from the point of regulators as the literature shows that bank profitability is an important factor of financial distress and bank crisis (Demirguc-Kunt and Detragiache, 2000). Furthermore, the factors that explain the profitability in state-owned banks would be of interest to regulators as well. Finally, our findings deepen our understanding of the dynamics in Islamic banking sector.

Keywords: Islamic banks, ownership, state banks, private banks, profitability JEL Codes: G21, G28, G32

\section{REFERENCES}

Beck, T., Demirgüç-Kunt, A., \& Merrouche, O. (2013). Islamic vs. conventional banking: Business model, efficiency and stability. Journal of Banking \& Finance, 37(2), 433-447

Carvalho, D. (2014). The real effects of government-owned banks: Evidence from an emerging market. The Journal of Finance, 69(2), 577609.

Demirgüç-Kunt, A., \& Detragiache, E. (2000). Monitoring banking sector fragility: a multivariate logit approach. The World Bank Economic Review, 14(2), 287-307. 
Dinç, I. S. (2005). Politicians and banks: Political influences on government-owned banks in emerging markets. Journal of Financial Economics, 77(2), 453-479.

Khwaja, A. I., \& Mian, A. (2005). Do lenders favor politically connected firms? Rent provision in an emerging financial market. The Quarterly Journal of Economics, 120(4), 1371-1411.

La Porta, R., Lopez-De-Silanes, F., Shleifer, A., (2002). Government ownership of banks. Journal of Finance, 57(1), 265-301.

Sapienza, P. (2004). The effects of government ownership on bank lending. Journal of Financial Economics, 72(2), 357-384.

Shleifer, A. (1998). State versus private ownership. Journal of Economic Perspectives, 12(4), 133-150.

Shleifer, A., \& Vishny, R. W. (1994). Politicians and firms. The Quarterly Journal of Economics, 109(4), 995-1025.

Shleifer, A., \& Vishny, R. W. (1997). A survey of corporate governance. Journal of Finance, 52(2), 737-783.

Stiglitz, J. E. (1993). The role of the state in financial markets. The World Bank Economic Review, 7, 19-52. 